\title{
16. Yüzyıl Osmanlı Kitap Sanatlarında Farklı Bir Uygulama: Şâh u Gedâ Mesnevisinin Çiçek Baskılı Kâğıtları
}

\author{
SAVAŞ MARAŞLI* \\ savasmarasli@nevsehir.edu.tr \\ ORCID ID 0000-0002-6685-9438
}

Öz: 16. yüzyıl şairlerinden Taşlıcalı Yahya Bey’in mesnevilerinden biri olan Şâh u Gedầnın Amasya II. Bayezid İl Halk Kütüphanesi 2067'de kayıtlı olan nüshasının farklı teknik kullanılarak yapılmış sayfa süslemeleri ile çağdaşı olduğu düşünülen bazı eserlerin süslemeleri arasında görülen benzerlikler bu çalışmanın çıkış noktası olmuştur. Şâh u Gedânın natüralist üslûptaki çiçekleri dönemin süsleme modasını belirlemiş olan Karamemi üslûbunu akla getirmekle birlikte kalpla boyama yoluyla elde edilmiş olmaları, dönemin teknikte seri arayışları olarak görülebilir. Bu arayışın nedenlerinden biri de 16. yüzyıl İstanbul’unun belirli semtlerinde oluşmuş olan kitap pazarlarına rağbet ederek bu pazarları canlı kılan yabancıların taleplerini karşılamadaki kaygilar olmalıdır. Bu durum 16. yüzylldan itibaren İstanbul'dan Avrupaya taşınan ve benzer teknikle yapıldıkları düşünülen albümlerden de anlaşılır. Konusu İstanbul'da geçen bir aşk öyküsü olan Şâh u Gedânın sayfa yüzeylerinde hafif renkler kullanılarak boyanmış çiçeklerine ve araya serpiştirilmiş hayvan figürlerine ilham kaynağ önerisi ise dönemin İstanbul'unun popüler mekânlarından olan çiçek bahçeleri ve buralarda yetiştirilen çiçeklerdir.

Anahtar kelimeler: Osmanl, 16. yüzyıl, Şâh u Gedâ, Kitap sanatları, Natüralist üslûp.

\section{Giriş}

Taşlıcalı Yahya Bey'in hamsesinde yer alan mesnevilerden biri olan Şâh u Gedâ klasik aşk mesnevileri içinde konusu İstanbul'da geçen bir eser olup, 16. yüzyıl İstanbul'u ile ilgili de önemli bilgiler verir. At meydanı (Sultanahmet Meydanı) ve Ayasofya gibi muhitlerin geniş tasvirlerle anlatıldığ bakımından Şâh ve Gedânın aşklarını irdelemektedir. ${ }^{1}$ Konu bakımından Osmanlı edebiyatının sevilen aşk hikayelerinden biri olduğunu 18. yüzyılda ait tereke kayıtlarında sıkça karşılaşılmasından da anlamaktayız. ${ }^{2}$ Eserin, Türkiye’de değişik kütüphanelerde 26 nüshası olmakla birlikte, Amasya nüshasından bahsedilmez. Yaklaşık

\footnotetext{
* Dr. Öğr. Üyesi, Nevşehir Hacı Bektaş Veli Üniversitesi, Fen Edebiyat Fakültesi, Sanat Tarihi Bölümü. 1 Türkiye Diyanet Vakfı İslam Ansiklopedisi, İskender Pala, İstanbul: Türkiye Diyanet Vakfı Yayınları, 2001, "Divan Edebiyatında İstanbul" maddesi.

2 İsmail E. Erünsal, Osmanlılarda Sahaflık ve Sahaflar, İstanbul: Timaş Yayınları, 2013, s.156-175.
} 
1540’larda yazılmış olabileceği ifade edilen, Şâh u Gedẩnın, daha Taşlıcalı Yahya hayattayken istinsah edilmiş nüshaları bulunmaktadır. ${ }^{3}$ Amasya II. Bayezid İl Halk Kütüphanesi env. no. 2067'de kayıtlı olan nüshası, edebi içeriği dışında metnin etrafına yapılmış baskı bezemeleri ile bu çalışmaya konu olmuştur.

Eserin sahibi Taşlıcalı Yahya; Yavuz Sultan Selim, Kanunî Sultan Süleyman, Sarı Selim, III. Murat olmak üzere dört padişah görmüş ve 1582 senesinde 93-94 yaşlarında ölmüş olma ihtimaline göre 1488-1489 yıllarında doğmuştur ${ }^{4}$. Bir asker şair olarak katıldığı Yavuz Sultan Selim'in 1514'te Çaldıran ve 1516'da Mısır seferlerinin ardından bunları Kanunî döneminde 1526'da Viyana, 1532'de Alman seferleri izlemiş, yine Kanunînin Irakeyn seferleri ile de bu durumu devam etmiştir ${ }^{5}$. Ömrü seferlerde geçen şair, aynı zamanda Kanunî dönemi ile birlikte alimlerin ve şairlerin sohbet meclislerinde kendine itibarlı bir yer bulmuştur. Irakeyn seferi sırasında şair Hayâlî Bey ile birlikte Fuzûlî ile tanışma fırsatını da yakalamış ve sahib-i seyfü kalem (kalem ve kılıç sahibi) olarak hayatını devam ettirmiştir. 1548'de İbrahim Paşa'nın öldürülmesinin ardından Rüstem Paşa ile kurduğu yakınlık Fatih Sultan Mehmed’in kurduğu Eyüb Vakfına mütevelli olmasını sağlar. 1553 yılında Kanunînnin Nahcivan Seferi sırasında oğlu Şehzade Mustafa’yı idam ettirtmesi, Taşlıcalı Yahya’yı derinden üzmüş ve Şehzadenin entrikalar sonucu katledilmesi üzerine ünlü mersiyesini yazmiştır.

\section{Meded meded bu cihanın yıkıldı bir yanı Ecel Celâlileri aldı Mustafa Hân' 1}

Dizeleriyle tanıdığımız mersiyesi, Yeniçeriler arasında yankılanmış Kanunînin damadı ve aynı zamanda veziri olan Rüstem Paşa'nın azline sebep olmuştur. Ancak bu durum kısa sürmüş Rüstem Paşa'nın tekrar göreve gelmesi ile Taşlıcalı Yahya da gözden düşmüşsür. ${ }^{8}$

\section{Şâh u Gedâ Nüshasının Tanıtımı}

Şâh u Gedâ mesnevisinin Amasya II. Bayezid İl Halk Kütüphanesi env. no 2067'de kayıtlı olan nüshası bordo renkli deriden yapılmış cilde sahiptir. Ön kapak, arka kapak ve miklep kompozisyon bakımından uyum içerisinde olup desen kompozisyonu tam zeminlidir. Motifler alttan ayırma tekniğinde yapılmış, yani zemin yaldızlanmış motifler ise deri renginde bırakılmıştır. Motif çeşidi bakımından rûmi, palmet, hatayi, gonca ve pençler görülmektedir. Merkezden başlayarak 4/1 simetrinin uygulandığ kapaklarda kompozisyon, üzerinde motiflerin yer aldığı helezonlardan oluşmakta-

\footnotetext{
3 Kazım Yoldaş, “Taşlıcalı Yahyâ Bey Şâh u Gedâ (inceleme-metin)”, Yüksek Lisans Tezi, İnönü Üniversitesi, 1993. s.19.

4 Ahmet Atila Şentürk, “En Hazin Mersiye’nin Şairi: Taşlıcalı Yahya Bey”, Dil ve Edebiyat Dergisi, 26 (2011), s.28. 5 Şentürk, "En Hazin Mersiye’nin Şairi: Taşlıcalı Yahya Bey”, s.28.

6 Türkiye Diyanet Vakfı İslam Ansiklopedisi, Bayram Ali Kaya, İstanbul: Türkiye Diyanet Vakfı Yayınları, 2011, "Taşlıcalı Yahyâ" maddesi.

7 Halil İnalcık, Has-bağçede 'Ayş u Tarab Nedîmler Şâîler Mutrîbler, İstanbul: Türkiye İş Bankası Kültür Yayınları, 2015, s.394.

8 Günay Kut, "Payitaht İstanbul'un Sultan Şairleri (Seyf ve'l-Kalem Sahipleri)", İlmi Araştırmalar Dil, Edebiyat, Tarih İncelemeleri Dergisi, 9 (2000), s.169.
} 
dır. 202 yapraklı eserin nerede kim tarafından istinsah edildiği ya da müzehhibin kim olduğu bilgisi bulunmamaktadır. Kitabın $2 \mathrm{~b}$ ve 3 a yapraklarında başlık bölümlerinde müellifin ismi ve eserin adı geçmektedir. Dönemin bahçe dünyasının moda çiçekleri ile tezyin edilmiş sayfa yüzeyleri kalıp baskı boyama yoluyla elde edilmiştir (Resim 1-2). Sayfaları süsleyen çiçeklerin birden fazla tip ve cinsinin kullanılması, ayrıca bunların serbest tarzda metin etrafına yerleştirilmesi ile monotonluk giderilmiştir. Topraktan çıkan gonca ya da açılmış güller, laleler, sümbül, sılklamen, karanfil, zambak, aynı safa, nergis ve yer yer ot kümeleri ile belli sayfalarda tekrar eden papağan, tavus kuşu, öküz ve tavşan gibi hayvan motifleri kullanılmıştır.

Yazmanın sayfalarında motiflerin belirli aralıklarla tekrar etmesi, sayfa tasarımlarının arkalı önlü sayfalarda aynı şekilde yer alması, sayfaların süslenmesinde bir çeşit kalıp kullanıldığını göstermektedir. Bu da muhtemelen kuvvetlendirilmiş kâğıt ya da deri olmalıdır. Derinin ince detaylarda kesilmesinin zor olacağından dolayı kâğıt kullanıldığ 1 düşünülebilir. Motifin şekline göre kesilen kalıpların yüzeyleri istenilen renge göre boyanıp, kâğıda bastırılması ile süslemenin yüzeye çıkması sağlanmıştır. Şâh u Gedầnın arka sayfalarında da aynı kompozisyonun görülmesinin sebebi budur. Yani boyanmış kalıplar, muhtemelen hafif nemli kâğıda bastırıldığı için arka sayfalara da aynı desen çıkmıştır. Motiflerin içlerinde görülen renklerin hafif olması, renklerin patlamaması, daha doğal görünmesi için sulandırılmış olmalarıyla alakalı olmalıdır. Asıl yüze basılan desenlerin yaldızla tahrirlenmesi ise belki de bu ayırımı görebilmek içindir. Sınırlara yaldızla hat çekilmesi, desenleri daha belirgin ve estetik hale getirmiştir. Bu şekilde sayfa kenarlarının süslenmesinde hem kolaylık ve hız hem de çeşitlilik kazandırılmış olur. Süsleme yapılacak motiflerin kâğıttan kesilerek oluşturulması, bir yanıyla Şâh u Gedầyı kat'ı sanatına yakınlaştırırken görünüş itibariyle hafif renkli oluşu ise şikaf ${ }^{9}$ tarzında yapılmış tezhipleri akla getirmektedir. Avrupa'da ise çoğunluğu Osmanlı topraklarından gitme bu tarz süslenmiş kâğıtlara silüet kâğıt adı verilir. ${ }^{10}$

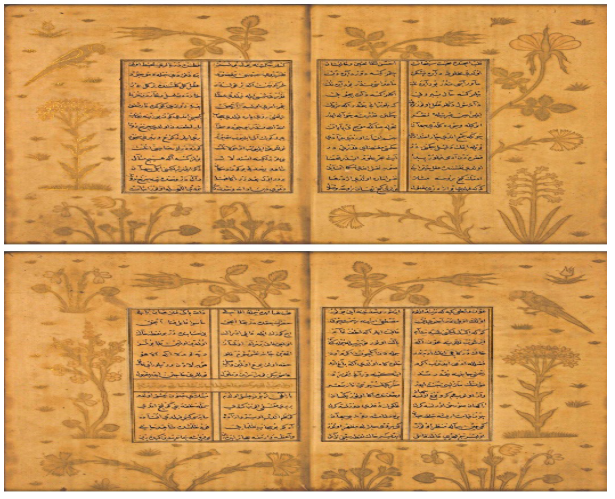

Resim 1. Şâh u Gedâ. 5b-6a.

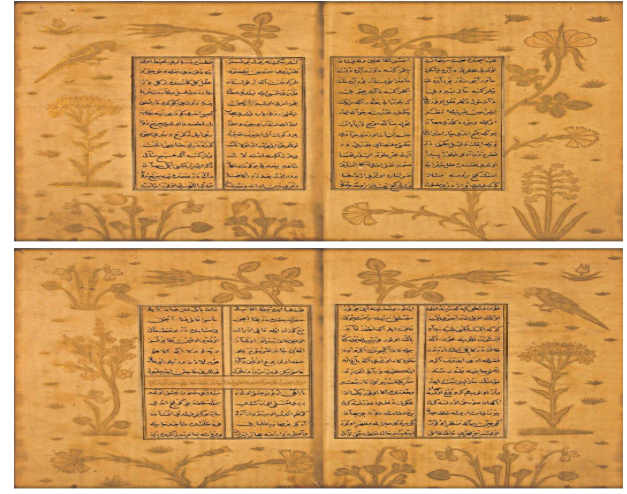

Resim 2. Şâh u Gedâ. 6b-7a.

9 Hafif renklendirilmiş altınla yapılan süslemelere şikaf denilmektedir. Bk. Gülbün Mesera, “Türk Tezhip ve Minyatür Sanatı", Sandoz Bülteni, 25 (1987), s.13.

10 Nedim Sönmez, Miniatur Geschichten Die Sammlung Indischer Malerei Im Dresdner Kupferstıch- Kabinett, Dresden: Sandstein; Bilingual edition, 2017, s.123-127. 


\section{Şâh u Gedâ ile Benzer Çağdaşı Örnekler}

Osmanlı’nın 16. yüzyılı edebiyat ve sanatsal faaliyetler bakımından oldukça zengin ve yoğun bir dönemidir. Edebiyat alanında hâmi-şair ilişkisine dayalı bu elverişli ortam, şairlerin, yazarların, hattatların, nakkaşların, müzehhiblerin ve müzisyenlerin bir arada olduğu bir çevre sunar. Bu muhitin isimlerinden biri olan Taşlıcalı Yahya, Gazalî mahlaslı Deli Birader, Hayalì Bey, Fethullah Ârif Çelebi, Bakî, Fevrî, Nakkaş Bâlizade Rahmî, Edayî, Sürurî, Gubarî, Lamî̀ Çelebi, Edirneli Nazmî̀, Ubeydî ve Dầ gibi ünlü şairlerle birlikte adı anılan ünlü biridir. ${ }^{11}$ Devrin Kanunî Sultan Süleyman (muhibbî) gibi bazı Osmanlı sultanları ve şehzadelerinin aynı zamanda şair olmaları şiiri bu devirde baskın sanat dalı haline getirirken yazmacılık faaliyetlerinin de geliştiği düşünülebilir. Böylesine üretken ve bazen de kolektif işlerin yapıldığı bir ortamda kitap sanatları alanlarında çalışan sanatçllara çok iş düştüğü muhakkaktır.

Örneğin 1500'lü tarihlerde Balıkesir'den İstanbul'a gelen dönemin ünlü şairlerinden Zât înin Bayezid cami avlusunda reml (fal) dükkânı açtığı ve burada şairlerinin buluştuğundan bahsedilir. Karşıllkl 1 şiirlerin okunup sohbetlerin yapıldı ı̆ı bu ortamlarda Hayâlî ve Taşlıcalı Yahya Bey'ler de vardır. ${ }^{12}$ Zâtînin bir şairler meclisi olarak da kullandığı dükkânı eski ve yeni şairlerin-yazarların bir araya geldiği, dönemin uğrak yerlerinden biridir. Zât tî, dükkânında kitap kopya etmek dışında divanlara serlevha-

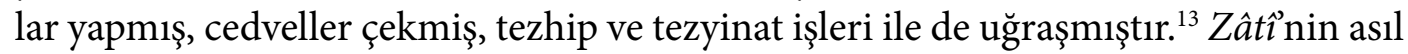
gelişimini 17. yüzyılda yaşayacak olan çarşı ressamlığının öncülerinden biri olduğu düşünebilir. ${ }^{14}$ Çarşı ressamları Osmanlıda yabancıların uğrak yerleri olan çarşılarda esnaflık yapan ve saraydan bağımsız çalışan sanatç̧lar için kullanılan bir tabirdir. ${ }^{15}$ İstanbul'un fethinden sonra Ayasofya’nın arka taraflarında Arslanhâne denilen eski bir Bizans kilisesinin üst katında çalıştıklarından bahsedilir. ${ }^{16}$

16. yüzyılda Osmanlı’nın elde ettiği askeri ve siyası başarılarının, Avrupa ile olan ilişkilerine kültürel ve sanatsal açıdan yeni bir bakış açısı kazandırdığı muhakkaktır. Örneğin Avrupa’dan Osmanlı’ya gelen elçiler, üst düzey yöneticiler ve tüccarların beraberlerinde Avrupa’ya taşıdıkları albümler, İstanbul'da başta kitap üretim işleri olmak üzere sanatsal faaliyetlerin hız kazanmasına neden olmuştur. Yabancıların, çarşı ressamlarına hazırlattıkları ve Osmanlı'dan esintiler taşıyan bu albümlerin içlerine bir nevi günlük gibi kendi dillerinde yazılar yazıp anı olarak ülkelerine götürdüklerinden bahsedilir. ${ }^{17} \mathrm{Bu}$ sipariş ve satın alma yollarla kitapların Avrupa'ya taşınması ilerde öyle bir boyuta ulaşacak ki 18. yüzyılın başlarında Sadrazam Şehid Ali Paşa yabancılara kitap satışını yasaklayan bir hüküm çıkartmak durumunda bile

11 Mustafa İsen, “XVI. Yüzyılda Siyasal, Kültürel ve Edebî Hayat”, 16. Yüzyıl Türk Edebiyatı, haz., Yekta Saraç, Muhsin Macit, Eskişehir: Anadolu Üniversitesi Açıöğretim Fakültesi Yayınları, 2011, s.10.

12 İnalcık, Has-bağçede 'Ayş u Tarab Nedîmler Şâîrler Mutrîbler, s.243.

13 İnalcık, Has-bağçede ‘yyş u Tarab Nedîmler Şâîrler Mutrîbler, s.243.

14 Çarşı ressamlığı konusunda bk. Filiz Çağman, Kat'ı Osmanlı Dünyasında Kâğıt Oyma Sanatı ve Sanatçıları, İstanbul: Aygaz A.Ş. Yayınları, 2014, s.224-241.

15 Metin And, Osmanlı Tasvir Sanatları: 1 Minyatür, İstanbul: Türkiye İş Bankası Kültür Yayınları, 2004, s.15-17. 16 Osmanlı Ansiklopedisi, Çiçek Derman, Ankara: Yeni Türkiye Yayınları, 1999, “Osmanlı Asırlarında Üslûp ve Sanatkarlarıyla Tezhip Sanatı" maddesi.

17 And, Osmanlı Tasvir Sanatları: 1 Minyatür, s.15-16. 
kalacaktı. ${ }^{18} \mathrm{Bu}$ albümlerden bazıları resimli, kat'ı ya da bu çalışmada ele alınan Şâh u Gedâ nüshasında olduğu gibi kalıpla boyama tekniğinde hazırlanmışlardır.

Dönemin İstanbul'unda dışarıya iş yapan çarşı ressamlarının yaptığı çalışmalar ile Şâh u Gedầnın süslemelerinin üretildiği ortam arasında yakın ilişkiler olduğu âşikardır. Bunu, daha çok yabancılar için hazırlanmış ve günümüzde farklı ülke ve kütüphanelere dağılmış olan ${ }^{19}$, Şâh $u$ Gedâ ile benzer teknik ya da süsleme üslubunda hazırlanmış albümlerden anlamaktayız. Bu albümlerden biri Peter Mundy albümüdür. ${ }^{20}$ Albüm, 1616 yılında İstanbul'a gelen İngiliz bir tüccar tarafından muhtemelen çarşı ressamlarına sipariş edilmiş ve 1618 yılında Londra'ya götürülmüştür. ${ }^{21}$ Albümün içerisinde yapıştırma tekniği ile yapılmış 59 minyatür ve minyatürlerin

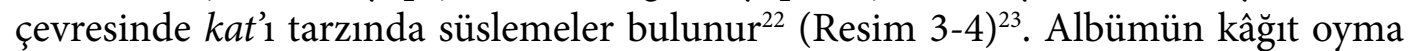
süslemeleri ile Şâh u Gedâ süslemeleri arasında benzerlikler vardır (Resim 5). Mundy albümünde çiçek boylarının figürlere göre orantısızlığına benzer bir durum Şâh $u$ Gedâ süslemelerinde de görülür. Metin kısmına göre çiçekler iri ve kabadır. Ancak Şâh u Gedâ nüshasındaki süslemeler kâğıt oyma ve yapıştırma tekniğinde yapılmamıştır. Bir çeşit kalıpla boyama tekniği kullanılmıştır. Farklı teknikler kullanılmış olsa da her iki örnekte de kullanılan çiçek ve ağaçlar içerik ve şekil olarak benzerdir ve kalıplaşmış temalardan faydalanılmıştır. Kalıpla boyama işi ve kat'ı sanatı arasında hem kullanılan çiçekler hem de teknik olarak benzerlikler görülür. İkisinde de arzu edilen motifler kâğıtlardan kesilerek yapılır. Ancak kat'ı da bu kesilen kâğıtlar sayfada belirlenen yerlerine yapıştırılır. Kalıpla boyamada ise kesilen kâğıtlardan elde edilen kalıplar sayfa yüzeyinin boyanması için kullanılır.

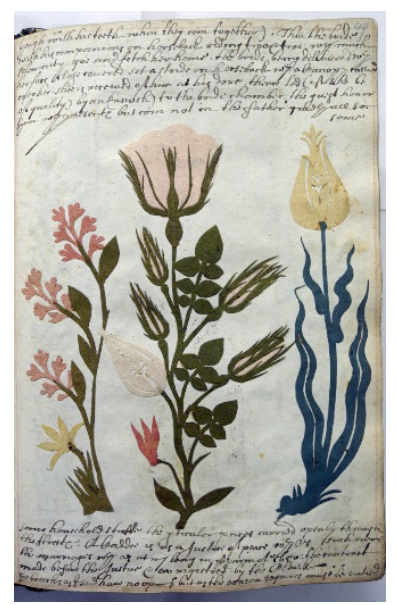

Resim 3. Peter Mundy Albümü. 49a.

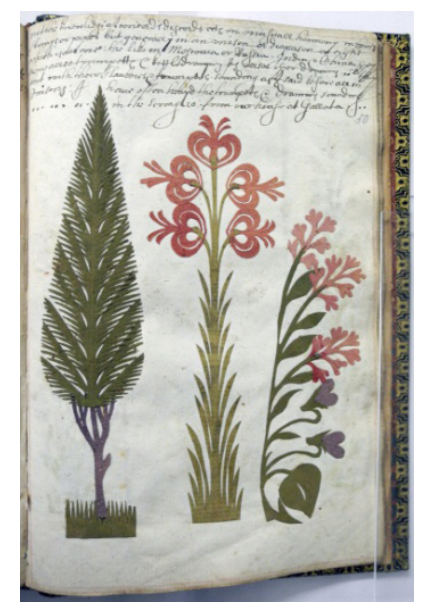

Resim 4. Peter Mundy Albümü. 50a.

18 Erünsal, Osmanlılarda Sahaflı ve Sahaflar, s.102.

19 And, Osmanlı Tasvir Sanatları: 1 Minyatür, s.15-16.

20 Albüm, The British Museum 1974-6-17-013’da kayıtlıdır. Bk. Filiz Adıgüzel Toprak, "1618 Tarihli Peter Mundy Albümü: Figürler Üzerine Bir İnceleme”, Sanat Dergisi, 22 (2012), s.69-83.

21 Toprak, “1618 Tarihli Peter Mundy Albümü: Figürler Üzerine Bir İnceleme”, s.70-71.

22 Toprak, "1618 Tarihli Peter Mundy Albümü: Figürler Üzerine Bir İnceleme”, s.73.

23 Albümün içerisindeki resimler için bk. "Peter Mundy albümü”, Son Güncelleme 30 Mayıs 2018, http://www. britishmuseum.org/research/collection_online/search.aspx?people=27168\&peoA=27168-3-18. 


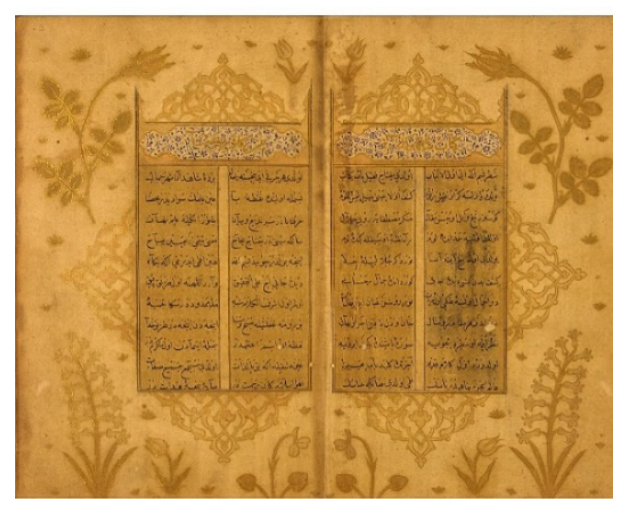

Resim 5. Şâh u Gedâ. 2b-3a.

Peter Mundy albümü ve Şâh u Gedâ yazmasının esinlendiği erken tarihli bir çalışma, 16. yüzyılın ilk çeyreğine tarihlenen kat'ı ustası Efşancı Mehmed'e atfedilen kat'ı tekniğinde yapılmış çiçek bahçesi olabilir (İstanbul Üniversitesi Kütüphanesi, F. 1426, y. 47a). Kendinden sonraki çiçek bahçesi temalı çalışmalara kaynak olduğu düşünülen eserde, siyah bir fon üzerine yapıştırılmış bahar ağaçları, serviler, güller, laleler, karanfiller, süsenler, sümbüller, nergis, menekşe, yasemin ve mineler döneminin Osmanlı bahçe dünyasının bir yansıması gibidir. ${ }^{24}$ Benzer süslemelere Şehzade Mehmed için hazırlanmış ve tarihsiz bir eser olan Hadis-i Erbain nüshasının lake cildinde de rastlanır (Topkapı Sarayı Müzesi Kütüphanesi, E.H. 2851). Karamemi üslubunu yansıtan lake cildi (Resim 6), Efşancı Mehmed’e atfedilen kat'ı tekniğinde yapılmış çiçek bahçesi ile kompozisyon açısından benzerlik taşır. ${ }^{25}$ Dolayısıyla Hadîs-i Erbaîn'in lake cild kapağında yer alan ve serbest tarzda yerleştirilen bahar açmış ağaçlar ve topraktan çıkan natüralist çiçeklerin Şâh u Gedâ süslemeleri ile benzerliği dikkati çekicidir (Resim 7).

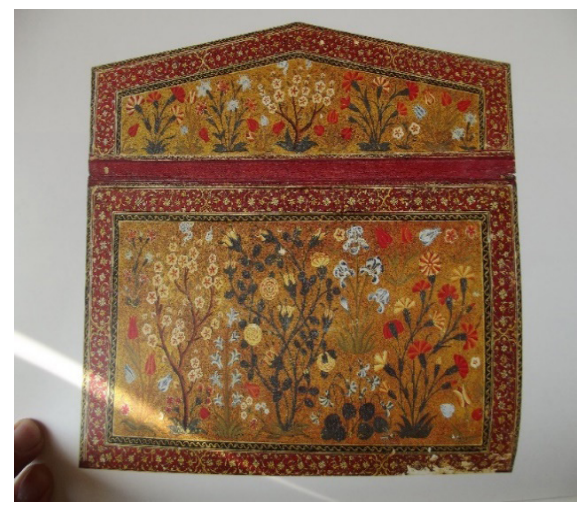

Resim 6. Hadis-i Erbain nüshasının lake cildi.

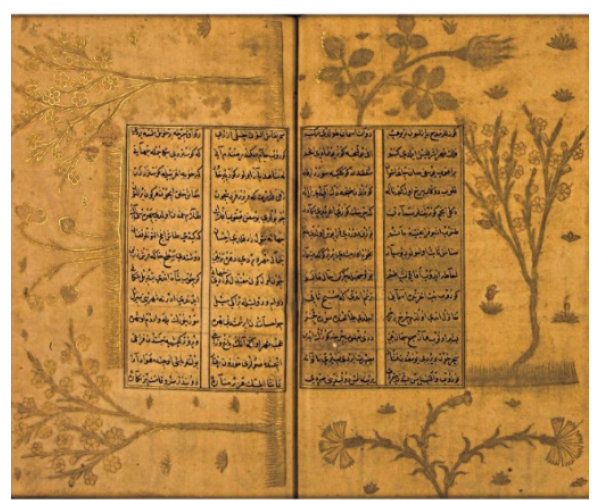

Resim 7. Şâh u Gedâ. 77b-78a.

16. yüzyılda dönemin uygulanmış bir tekniği olarak öne çıkan kalıpla boyanmış anı albümlerinin Avrupa'da talep gördügüne bir örnek bugün Dresden Staatliche Kunstsammlungen'de bulunan Kurfürst August albümünde yer alan kalıpla boyama tekni-

24 Çağman, Kat'ı Osmanlı Dünyasında Kâğıt Oyma Sanatı ve Sanatçıları, s.105.

25 Çağman, Kat’ı Osmanlı Dünyasında Kâğıt Oyma Sanatı ve Sanatçıları, s.125. 
ğinin uygulandığı bir kâğıttır. ${ }^{26} 1582$ tarihli albüm kapağı kumaştan bir cilde sahiptir. Kıvrık dallar üzerinde hatayiler hançeri yapraklar ve sümbüllerle kaplı cildin bezemeleri 16. yüzyıl geleneğine uygun hazırlanmıştır. Kıyafet resimlerinin de yer aldığ 1 albümün katalog 3d 114/77'de bulunan kalıp boyama tekniğinde yapılmış sayfa süslemesi Şâh u Gedầya benzer olması ve tekniğin ne kadar yaygın olduğunu göstermesi açısından önemlidir (Resim 8$)^{27}$. Sayfa kenarlarına kalıpla gelişigüzel yerleştirilen karanfil, servi ve lale motifleri hafif renklendirilmiş olup Şâh u Gedâ nüshasina göre özensiz işçiliktedir (Resim 9).

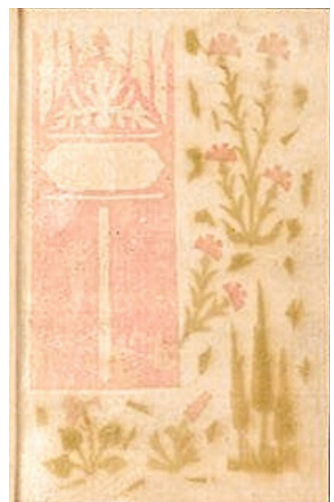

Resim 8. Kupferstich-Kabinett, Staatliche Kunstsammlungen Dresden. Inv. Ca 114/77.

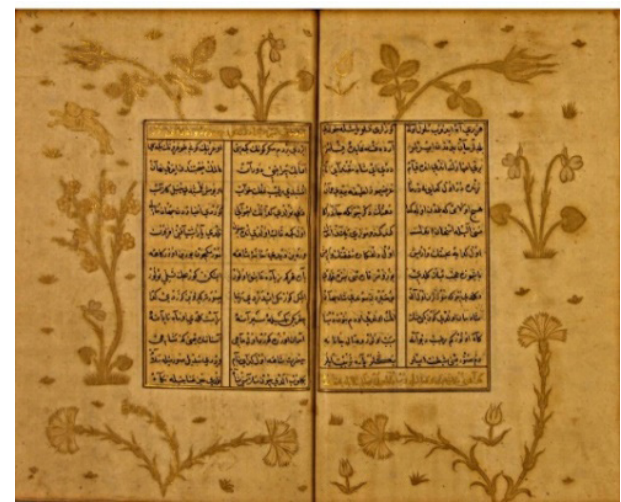

Resim 9. Şâh u Gedâ. 66a.

Aynı teknikle yapılmış albümlerden bir diğeri ise günümüzde Hollanda Hague Koninklijke Bibliotheek National library of the Netherlands'da bulunur. ${ }^{28}$ Kalıpla boya-

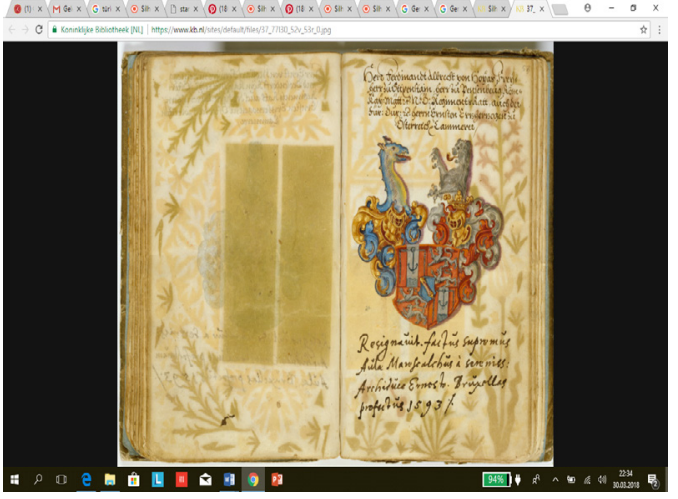

Resim 10. Koninklijke BibliotheekNational library of the Netherlands'da albüm. 77 L 30, fol. 52b, 53 a.

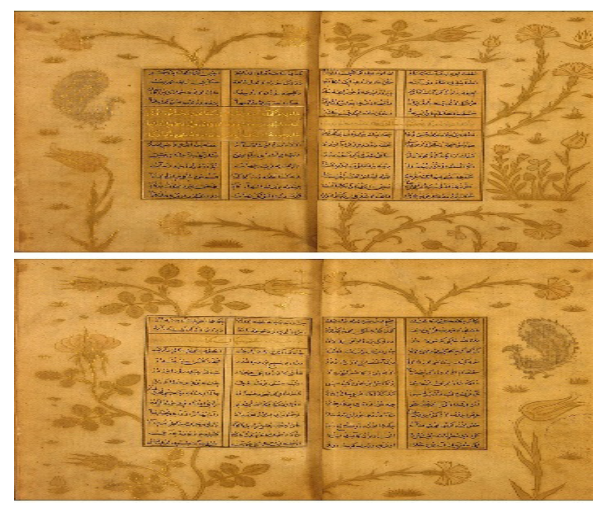

Resim 11. Şâh u Gedâ nüshası. 34b-35a.

manın yapıldığı sayfaların bir tarafının üzerinde Habsburg Alman İmparatoru Rudolf II 'nin arması görülür ve 1580-1602 tarihlidir. ${ }^{29}$ Şâh u Gedâ süslemelerinin kopyası

26 Kupferstich-Kabinett, Staatliche Kunstsammlungen Dresden, Inv. Ca 114/77.

27 Resim için bk. Sönmez, Miniatur Geschichten Die Sammlung Indischer Malerei Im Dresdner KupferstıchKabinett, s.127.

28 Hollanda Ulusal Kütüphanesinde bulunan albüm 81 yaprak olup 189 x $121 \mathrm{~mm}$. ölçülerindedir. 77 L 30, fol. 52v-53r. 16. Yüzyılın ikinci yarısında tüccarlarla batı Avrupaya getirilmiş Türk ya da İran kâğıtları olarak bahsedilmektedir. Bk. "silhouette paper", son güncelleme 25 Mayıs, 2018. https://www.kb.nl/en/themes/bookart-and-illustrated-books/decorated-paper/silhouette-paper.

29 Albüm erişimi için bk. "silhouette paper", son güncelleme 25 Mayıs, 2018. https://www.kb.nl/sites/default/ 
gibi duran süslemeler, sayfalarda metin için boş bırakılan alanın etrafında kaba-özensiz bir işçilik ile yapılmış olup tahrirsizdir. Buna rağmen karanfil, lale, sümbül ve siklamenler ayırt edilecek durumdadır (Resim 10-11).

16. yüzyılda Avrupa'ya gitmiş olan sipariş albümlere başka önemli bir örnek ise Georg Ringler Albümüdür. ${ }^{30} 1581$ yılında Strazburg'dan İstanbul'a gelen elçilik heyeti arasında yer alan Ringler'in bahçe çiçekleri ve bahar dallı ağaç motiflerinin kalıpları çıkartılarak baskı boyama yoluyla oluşturulmuş albümü ${ }^{31}, 16$. yüzyıl İstanbul sanat ortamıla ilgili önemli bilgiler verir. Albümde ${ }^{32}, 196$ sayfada kalıpla boyama tekniğ kullanılmıştır. Kâğıtlar düzensiz ve kaba bir şekilde kenarlardan çıkan bahar açmış ağaçlar ve lale, gül, sümbül, süsen çiçekleriyle bezenmiştir. Burada her bir motif için ayrı kalıp kullanılmış olup Koninklijke Bibliotheek National library of the Netherlan$d s$ 'da bulunan albümün süslemeleri ile çok benzerdir. Dolayısıyla Şâh u Gedâ ile de teknik ve üslûp olarak benzemektedir. Kaba, özensiz bir işçilik ile yerleştirilen çiçekler alışılmış formlarından uzaktır (Resim 12-13).

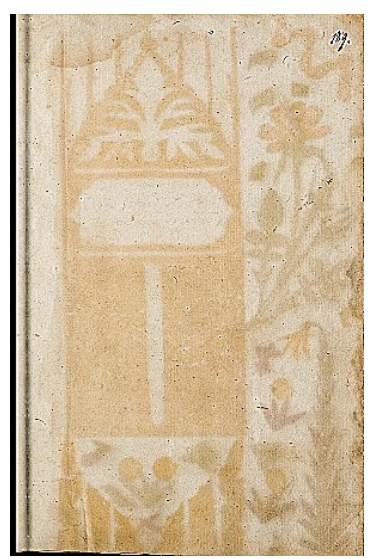

Resim 12. Georg Ringler Albümü. 189a.

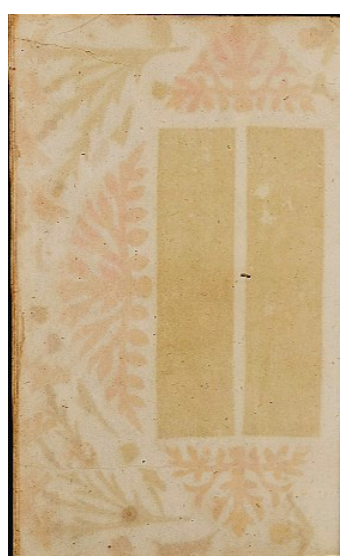

Resim 13. Georg Ringler Albümü. 37a.

Avrupalılar için hazırlanan bu albümler İstanbul'dan sahipleriyle alelacele yola çıkmak için sipariş verilmiş gibidir. Eğer öyleyse İstanbul merkezli kâğıt-kitap süsleme işlerinin yapıldığı hareketli bir sanat ortamı düşüncesi çok da yanlış değildir. Peki İstanbul'da bu işler nerede oluyordu? Bu sorunun cevabi İstanbul'a gelip giden yabancı elçilerin uğrak yerlerinden birisi olan Çemberlitaş'ta bulunan Elçi Hanı (Balyos Hanı) ile ilişkili olabilir. ${ }^{33}$ Sırf 1500-1700 yılları arasında Avusturya'dan İstanbul’a gönderilen elçilik heyetleri sayısının 120’yi bulmuş olması düşünüldügüünde ${ }^{34}$,

files/37_77130_52v_53r_0.jpg.

30 Württembergisches Landesbibliothek, Stuttgart (Codex hist. $8^{0} \mathrm{Nr} .5$ ).

$31 \mathrm{Bu}$ konuda bk. Sönmez, Miniatur Geschichten Die Sammlung Indischer Malerei Im Dresdner KupferstıchKabinett, s.17.

32 Albüme açık erişim için bk. "Stammbuch Georg Ringler”, son güncelleme 24 mayıs, 2018. https://www.leo-bw. de/web/guest/detail/-/Detail/details/DOKUMENT/wlb_digitalisate/digibib-bsz4176277182/ Stammbuch+Georg+Ringler+-+Codhistoct5.

33 Türkiye Diyanet Vakfı İslam Ansiklopedisi, Semavi Eyice, İstanbul: Türkiye Diyanet Vakfı Yayınları, 1995, "Elçi Hanı" maddesi.

34 Karl Tepy, "Nemçe İmparatorlarının İstanbul’a Yolladığı Elçi Heyetleri ve Bunların Kültür Tarihi Bakımından Önemli Tarafları”, çev., Bekir Sıtkı Baykal. Ankara Üniversitesi Dil ve Tarih-Coğrafya Fakültesi Tarih Bölümü Tarih Araştırmaları Dergisi, 12 (1969), s.248. 
Han’ın ve çevresinin önemi daha iyi anlaşılmaktadır. Batıdan ve doğudan gelen tüm seyyahların uğrak yerlerinden biri olan Han, Kapalıçarşı ve Bayezid caminin de bulunduğu bir bölgede olup, burada medreselerin sayıca fazlalığı dikkati çeker. Belki bu yüzden sahaf dükkânları da burada yer almıştır. İstanbul'da kitap ve kitap üretiminde kullanılan malzemenin ticaretinin yapıldığ mücellit dükkânları ${ }^{35}$ yerli ve yabancılar için alışveriş ortamı sağlamaktaydı. Bayezid cami avlusunda dönemin ünlü şairlerinden Zâtînin kitapçı dükkânının da olmasından yola çıkarak bölgeyi, kitap üretim işlerinin yapıldığı, sahafların bulunduğu ve Avrupalıların merakları neticesinde işleklik kazandığı bir pazar alanı olarak hayal edebiliriz. Yine Kanunî döneminin şairlerinden Keşfïnin de Kapalıçarşıłda sahaflık yapmak için dükkân kiralamass ${ }^{36}$, bir taraftan dönemin şairleri için yeni bir iş kolu oluştururken diğer taraftan bu mekânları kitap sanatlarının her kolunda ticaretinin yapıldığı pazarlarlar olarak öne çıkarmaktadır. Aynı dönemde Kapalıçarşı’nın etrafında 42 mücellid dükkânının varlığg $1^{37}$ çok sayıda kitap üretim işlerinin gerçekleştirildiğini gösterir.

Şâh u Gedầnın süslemeleri ile neredeyse birebir benzer çalışma, Topkapı Sarayı Müzesi Kütüphanesi Revan 738'de bulunan Muhibbi Divaninın 1565 tarihlerinde yapılmış olan nüshasıdır. ${ }^{38}$

Üslûp olarak Karamemi’nin eseri olduğu düşünülen Muhibbi Divanı nüshasının belirli sayfalardaki süslemeleri ${ }^{39}$ ile imzasız bir nüsha olan Şâh u Gedâ süslemeleri aynı dönemde aynı atölye ya da sanatçının elinden çıkmış gibi durmaktadır. ${ }^{40}$ Müstakil

35 Erünsal, Osmanlılarda Sahaflık ve Sahaflar, s.69.

36 Erünsal, Osmanlilarda Sahaflık ve Sahaflar, s.70.

37 Erünsal, Osmanlılarda Sahaflı ve Sahaflar, s.71.

38 Gülbün Mesera, “Kanuni Sultan Süleyman’ın Sernakkaşı Karamemi”, Hat ve Tezhip Sanatı. Haz., Ali Rıza Özcan, İstanbul: Kültür ve Turizm Bakanlığı Yayınları, 2009, s.373.

$39 \mathrm{Bu}$ dönem Saray nakışhânesinin başında bulunan Karamemi ile başlayan natüralist üslûpta çiçeklerin geleneksel kompozisyonlara dahil edilmesi yenilikçi bir yaklaşım olarak görülebilir. Bahçe çiçeklerinin yarı uslûplaştırılması ile oluşturulan bu yeni akımın öncüsünü Kanunînin şiirlerini içeren Muhibbî Divanı’nda görmekteyiz. Bu eserin üç nüshasından imzalı olan 1566 tarihli İstanbul Üniversitesi Kütüphane’si (T.5467) örneğinin natüralist tezhip örnekleri, dönemin imzasız başka eserlerinin kimliğinin belirlenmesinde de önemli bir dayanaktır. Yıldız Demiriz, Karamemi imzalı 1566 tarihli İstanbul Üniversitesi Kütüphane’si (T.5467) nüshasının baş sayfa tezhibindeki bahar açmış meyve ağacı tezhibi ile TSK. Y. 999'da kayıtlı Kur’an ve TSK. H. 1517'de kayıtlı Süleymannâme’nin baş sayfa tezhiplerindeki bahar açmış ağaçların üslûp açısından benzerliğine dayanarak bu eserleri Karamemi’ye atfetmektedir. Bunda Karamemi’nin, Muhibbî divanında natüralist tarzda yapılmış müstakil bir çiçek demetinin köklerinin üzerinde imzasının bulunması önemli bir dayanak oluşturmaktadır. Yıldız Demiriz, “16. Yüzyıl Kitap Sanatında Çiçek”, 16. Yüzyıl Osmanlı Kültür ve Sanatı Sempozyumu, İstanbul:11-12 Nisan 2000, s.146-147.

40 Karamemi tarzının izleri görülen diğer imzasız eserler arasında Topkapı Sarayı Müzesi Kütüphanesi'nde bulunan (Revan Köşkü, nr. 738; İÜ Ktp., TY, nr. 6976) Dîvân-1 Muhibbî tezhibi, aynı yerdeki (Revan Köşkü, nr. 824; Emanet Hazinesi, nr. 2851) lake cilt kabı ile 947 (1540) tarihli kırk hadis (Emanet Hazinesi, nr. 2851), Ahmed Karahisârînnin 953’te (1546-47) istinsah ettiği mushaf-1 şerif (Yeni Yazmalar, nr. 999), Kanûnî Sultan Süleyman tuğrası (Güzel Yazılar, nr. 1400), yine Topkapı Sarayı Müzesi Kütüphanesi’nde kayıtlı (Hazine, nr. 1517) 965 (1558) tarihli Ârifî Fethullah Çelebi’nin Şehnâme-i Âl-i Osmân adlı eserinin V. cildini oluşturan Süleymannâme’si, İstanbul Türk ve İslâm Eserleri Müzesi’nde kayıtlı (nr. 2191) 947 (1540) tarihli Hürrem Sultan vakfiyesi, İstanbul Üniversitesi Kütüphanesi’nde (FY, nr. 1426), Şah Mahmûd Nîşâûurî murakka1 diye bilinen albüm içindeki meşhur İranlı hattatların kıta tezhipleri zikredilebilir. Bu eserler tezhip tekniği, renk ve desen kompozisyonu bakımından Karamemi tarzında olmakla beraber saray nakışhânesinde çalışan pek çok uzman sanatkârın ortak işidir. Bk. Türkiye Diyanet Vakfı İslam Ansiklopedisi, Gülnur Duran, İstanbul: Türkiye Diyanet Vakfı Yayınlar, 2012, "Karamemi” maddesi. 
tarzda oluşturulmuş natüralist desenlerin yazmanın farklı sayfalarında tekrarlanması, sırt sırta gelen sayfaların bazen de karşı sayfaların eş olması, gül, lale, karanfil, sümbül, zambak, kardelen ve bahar açmış ağaçların her iki eserde de aynı üslûpla yapılması Karamemi üslûbunu taşıyan 1565 tarihli Muhibbi Divan'ı süslemeleri ve Şâh u Gedầyı ortak kılarken, aynı zamanda bahçe çiçeklerini yeni üslûpta süsleme dağarcığına kazandıran Karamemìnin de Şâh u Gedâ ile doğrudan ya da dolaylı ilişkileri olabileceğini gösterir. Muhibbi Divani'nın pervaz süslemeleri ile (Resim 14) ${ }^{41}$ Şâh u Gedâ süslemeleri (Resim 15) teknik, üslûp ve kompozisyon açısından neredeyse aynıdır. Her iki eserde dönemin bahçe kültürü ve çiçek dünyasından izler taşır. Çeşit çeşit güller, boy boy laleler, karanfil, sümbül, bahar dalları, süsen, siklamen, menekşe, servi hepsi benzer bir anlayış ve tekniğin ürünüdür.

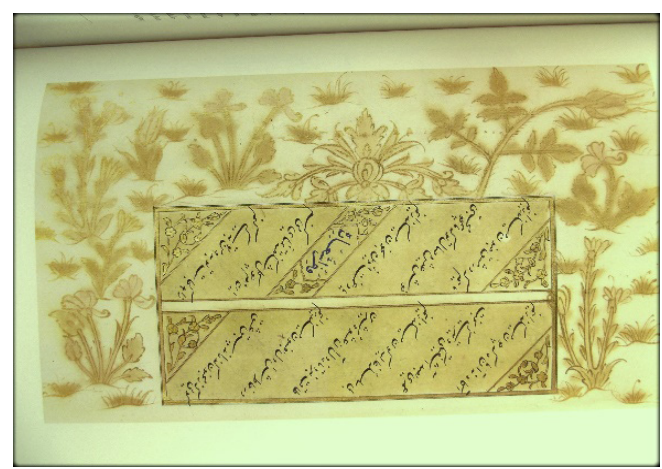

Resim 14. Topkapı Sarayı Müzesi Kütüphanesi Revan 738'de bulunan Muhibbi Divanı

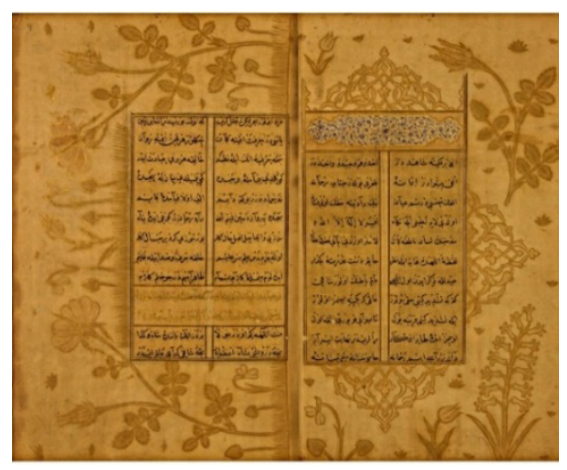

Resim 15: Şâh u Gedâ. 3b-4a.

Şâh u Gedâ nüshasına göre üzerinde nispeten daha çok çalışma yapılan 1565 tarihli Muhibbi Divanı nüshasının bahsettiğimiz sayfa desenleri için araştırmacıların farklı tanımlama yaptıkları görülür. Örneğin Yıldız Demiriz desenlerin bir çeşit kalıpla oluşturulduğundan ve konturların firça ile serbest bir şekilde çekilerek bir çeşit halkâr uygulaması yapıldığından bahseder. ${ }^{42}$ Filiz Çă̆man da bu teknik için özel olarak hazırlanan madeni kalıplarla ya da kalın kâğıttan yapılan kalıplarla püskürtmek suretiyle sayfanın boyandığı ve bu şekilde sayfanın diğer yüzüne de motifin çıkmasının sağlandığını belirtir. ${ }^{43}$ Süheyl Ünver ise şikaf tarzında dediği sayfalardaki nergis, gül goncası, açılmış gül, karanfil ve menekşelerin hafif yeşil ve pembe tonlarda ve silik bir şekilde yapıldığını ifade eder. ${ }^{44}$

\section{Dönemin Çiçek Bahçeleri ve Çiçekleri}

16. yüzyılda resimli, kat'ı ya da lake çalışmaların yanı sıra seri üretime daha uygun olan kalıpla boyanmış anı albümleri Osmanlı’yı yakından tanımak isteyen Avrupalı için birer dolaşım malzemesi olarak çoktan yerini almıştır. Bu albümlerdeki ortak özellik olan ve dönemin modası gibi duran Ef̧̧ancı Mehmed ya da Karamemi gibi

41 Muhibbi Divan resimli sayfa için bk. Filiz Çağman, Kat'ı Osmanlı Dünyasında Kâğıt Oyma Sanatı ve Sanatçıları, s.184.

42 Demiriz, “16. Yüzyıl Kitap Sanatında Çiçek”, s.147.

43 Çağman, Kat’ı Osmanlı Dünyasında Kâğıt Oyma Sanatı ve Sanatçıları, s.184.

44 Ahmet Süheyl Ünver, Müzehhip Karamemi. İstanbul: İstanbul Üniversitesi Yayınları, 1951, s.8. 
sanatçılara atfedilen natüralist üslûptaki çiçekli resim geleneği nereden geliyordu? $\mathrm{Bu}$ sorunun cevabını Osmanlının doğulu komşularıyla ilişkilerinde ve İstanbul'un çiçek bahçelerinde aramak gerekir. Dönemin sevilen meşguliyetlerinden biri olan çiçek yetiştiriciliğinin "moda” olması sanatçıları etkilemiş olmalı. Öyle ki, bu modayla beraber yaratılan Osmanlı imajının Avrupa’da yayılmaya başlamasıyla Avrupalının ilgisi Osmanlı’nın gündelik hayatına hatta bahçe kültürüne ve çiçek yetiştiriciliğine daha çok sirayet etmişti. Böylece İstanbul merkezli çiçek kültürünün ortaya çıkması ve bunun Avrupa'ya yayılması sağlandı. Bunda ise Avusturya elçisi Busbecq'in katkısı büyüktür. Busbecq 1555 tarihinde Edirne'den yazdığı mektubunda lale, sümbül, nergis çiçeklerini gördügünü söylemektedir. ${ }^{45} 8$ yıl İstanbul'da kalan yazar ülkesine dönerken lale soğanları da götürmüştür. ${ }^{46}$ Aralarında lale, sümbül, leylak gibi Osmanlı’ya özgü birçok çiçek türünün Avrupa’ya yayılmasında Busbecq ve beraberindeki heyet aktif rol oynamıştır. ${ }^{47}$ Büyükelçi Busbecq sadece lale soğanları değil İstanbul'da kaldığ süre içerisinde satın alınma ya da hediye edilen birçok eşyayı da beraberinde götürmüştür. Bunların içerisinde özellikle 240 adet yazma eser ise dikkati çeker. ${ }^{48} \mathrm{Bu}$

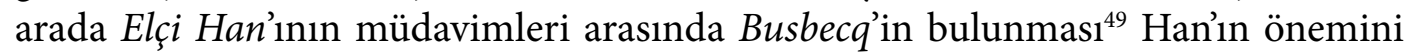
bir kez daha ortaya koyar.

18. yüzyılda kamusal alanlara dönüşünceye kadar padişah ve çevresinin inziva yerleri olan has bahçeler ${ }^{50}$ ve buralarda yetiştirilen çiçeklerin dönemin sanat dünyasında bir malzeme olarak yerini almaları şaşırtıcı değildir. Bir kere buralarda yer alan çiçekler her devirde bahçelerde sanat eserlerinde, şiirde, kitap süslemelerinde bu kültürün görsel sunumunu oluşturmuştur. ${ }^{51}$ Konusu aşk olan kitapların yazılması, sayfa kenarlarının dönemin modasına uygun şekilde çiçeklerle bezenmesinde, çiçekler hakkında yazılan kitaplar ya da söylenen şiirlerde özel ve (daha sonra) kamusal çiçek bahçelerinin etkisinin olduğu muhakkaktır. Nitekim Karamemìnin

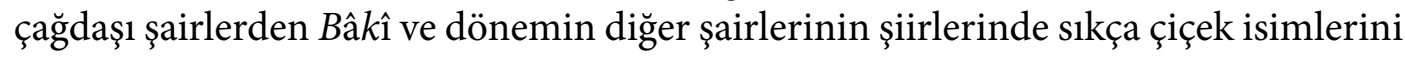
geçirmeleri bu kültürün edebi dile geçişini gösterir. Şairlere bu ilhamı veren muhtemelen dönemin bahar açmış meyve ağaçları ve aralarına serpiştirilmiş gül lale karanfil sümbül süsen menekşelerle donatılmış bahçeleri olmalıdır. Örneğin Bâkînin "bahar" üzerine yazılmış manzume ve gazellerinde sıkça dönemin çiçeklerinin isimlerini söylemesi ${ }^{52}$, bahsedilen ilişkiyi gösterir. Dönemin ortak mekân, ortak sanat algısı içerisinde fikir olarak yetişen çiçek üslubunun tüm sanat alanlarına yayılması ise şaşırtıcı değildir. Tabi bu yüzyıla "çiçek üslubu” denmesinde Kanunî döneminden

45 Ahmet Süheyl Ünver, “Türkiye'de Lale Tarihi”, Vakıflar Dergisi. 9 (1971), s.265.

46 Nurhan Atasoy, Hasbahçe Osmanlı Kültüründe Bahçe ve Çiçek, İstanbul: Aygaz A. Ş. Yayınları, 2002, s.49.

47 Tepy, "Nemçe İmparatorlarının İstanbul'a Yolladığı Elçi Heyetleri ve Bunların Kültür Tarihi Bakımından Önemli Tarafları", s.262.

48 Tepy, "Nemçe İmparatorlarının İstanbul’a Yolladığı Elçi Heyetleri ve Bunların Kültür Tarihi Bakımından Önemli Tarafları”, s.262-263; Erünsal, Osmanlılarda Sahaflık ve Sahaflar, s.99.

49 Tepy, "Nemçe İmparatorlarının İstanbul’a Yolladığı Elçi Heyetleri ve Bunların Kültür Tarihi Bakımından Önemli Tarafları”, s.257.

50 Tülay Artan, “İfade Biçimleri ve Mecraları İstanbul ve Ötesi (1600-1800)”, Osmanl Dünyası, haz., Christine Woodhead, İstanbul: Alfa Yayıncilık, 1. Bs., 2018, s.508.

51 İnalcık, Has-bağçede 'Ayş u Tarab Nedîmler Şâîrler Mutrîbler, s.281.

52 Zeynep Öz, “Bâkî Dîvânında Bahâriyye”, Divan Edebiyatı Araştırmaları Dergisi, 19 (2017), s.217-254. 
itibaren çiçeğe verilen önem etkili olmuş olmalıdır. ${ }^{53} 16$. yüzyll kitap süsleme sanatlarında görülen desen, teknik ve motif bakımından zengin içeriklerin bu dönemin yetiştirilen, slah edilen çiçekleri ve bahçe kültüründeki gelişmeler ile ilişkileri açıkça görülür. ${ }^{54}$ Çiçeklerin adeta görücüye çıktığ 1 Has bahçeler hakkında Tavernier şöyle demektedir;

"Bugüne kadar gelen eski bir gelenek veya kanun, Osmanlı sultanlarının yiyecek ihtiyaçlarını, bu bahçelerden elde ettikleri gelirlerle gidermelerini gerektirir. Bu yüzden, sultana ait İstanbul'un Avrupa ve Asya yakasında deniz kıyısı boyunca birçok bahçe vardır. Sarayın çeşitli bölümlerinde, çok miktarda çiçeğin olduğu küçük bahçeler görünür. Özellikle de bu tür bahçeler padişahın ve şüphesiz hanım sultanların dairelerinde bulunur. Sultanın bahçelerinin ve Topkapı Sarayı bahçesinin kahyası Bostanc1başı'ır. Etrafı servilerle çevrili yollardan oluşan Topkapı Sarayı'nın bahçesi, sarayın en büyük bölümüdür. Ama buraya fazla özen gösterilmemiş ve çoğu yerini dikenler kaplamıştır. Eğer padişahın bahçeye çıkacağı bilinirse, bostancılar gelip, onun geçeceği yolları temizlerler. Bu yolların dışındaki yerler, sebze veya meyve bahçeleriyle doludur. Çok miktarda çiçekler, frambuazlar ve salatalıklar yetiştirilir". ${ }^{55}$.

Boğaziçi ve Haliç’in kıyılarında yer alan saray dışı bahçelerin giderek yayılmaları buraları cazibe noktasına dönüştürmüştür. Bahçeler, havuzlar, şelaleler, nahıllar, buhurdanlar, kandiller ve rengarenk çeşit çeşit çiçeklerle süslenmiş ve devrin başta şair ve musikişinasları olmak üzere sanatkarların buluştuğu bu yerler artık sadece birer bahçe değil, sanatçıya ilham veren işret (eğlence) mekânlarıdır. ${ }^{56}$

\section{Şâh u Gedâ'da ki Hayvan Tasvirleri}

Şâh $u$ Gedâ 'yı hem çağdaşı olduğu düşünülen diğer benzer örneklere göre hem de Osmanlı kitap sanatları açısından özel kılan konulardan biri hayvan tasvirlerine yer verilmiş olmasıdır. Öküz, tavşan, papağan ve tavus kuşu gibi figürler çiçek ve

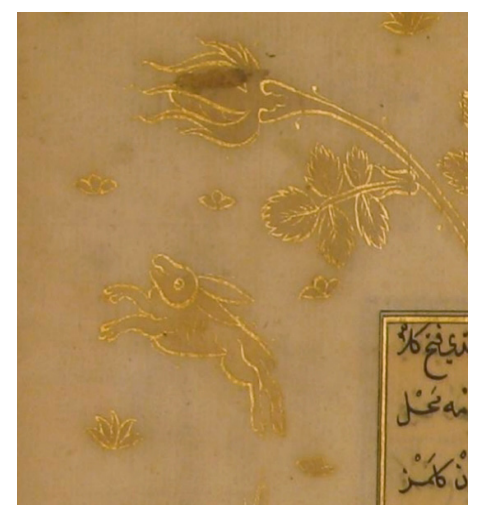

Resim 16. Şâh u Gedâ. $72 a$.

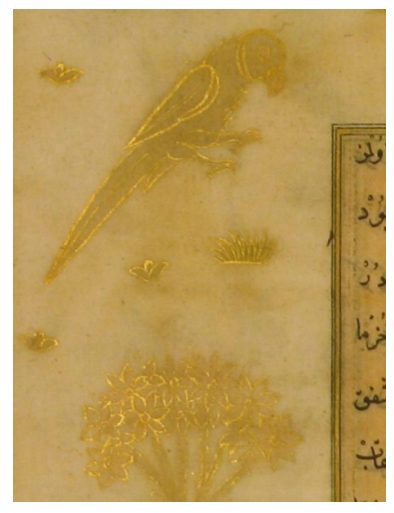

Resim 17. Şâh u Gedâ. 6a. Resim 18. Şâh u Gedâ. 40a.

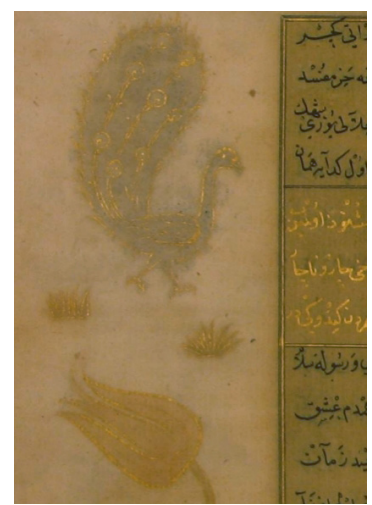

53 Atasoy, Hasbahçe Osmanlı Kültüründe Bahçe ve Çiçek, s.46.

54 Atasoy, Hasbahçe Osmanlı Kültüründe Bahçe ve Çiçek, s.46.

55 Jean Batiste Tavernier, Bir Fransız Seyyahın Gözüyle Topkapı Sarayı’nda Yaşam, Büyük Senyörün Sarayı, çev., Hâluk Yanardağ, İstanbul: Parıltı Yayınları, 2005, s.175.

56 Halil İnalcık, Has-bağçede Ayş u Tarab Nedîmler Şâîrler Mutrîbler, s.296. 
ağaç kompozisyonlarının içerisinde doğanın bir parçası olarak yerlerini almış ve bu oluşum belli sayfalarda tekrar etmektedir (Resim 16-18). Hayvanların sayfa içlerindeki konumları ve şekillerinin benzerliği kalıpla yapılmış oldukları fikrini desteklemektedir.

Hafif renklerle boyanan hayvanların belli özellikleri yaldızla tahrirlenerek vurgulanmıştır. Örneğin öküzün boynuzları ya da tavus kuşunun kuyruğundaki tüylerde yer alan gözler gibi. Öküzlerin benekli ve uzun çizgili olarak farklı iki desende yapılmalarının, cinslerinin farklılığına işaret etmek için olduğu düşünülmektedir. Ayrıca tahrir çizgilerinin farklılığından eserde birden fazla sanatçının çalışmış olabileceği sonucu da çıkarılabilir (Resim 19-20).

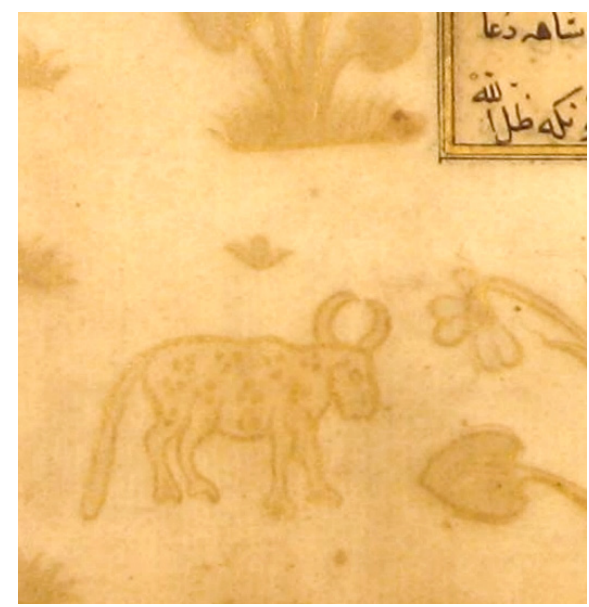

Resim 19. Şâh u Gedâ. $21 a$.

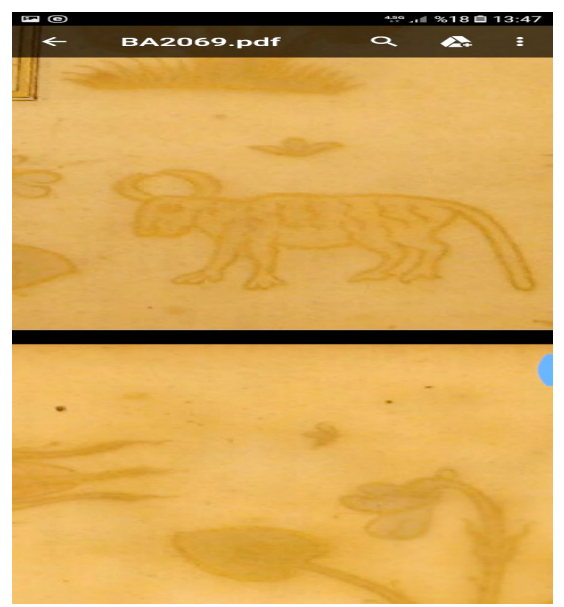

Resim 20. Şâh u Gedâ. $21 b$.

Eserde yer alan üslûplaştırılmış hayvan tasvirlerinin metaforik anlamları üzerine durmayacağız ancak Şâh u Gedầda görülen tasvirlerin hangi kültür çevreleriyle ilişkili olduğu hususunda birkaç cümle etmekte fayda var. Öncelikle Orta Asya kaynaklı hayvan üslûbunun Anadolu Türk-İslâm sanatına katkıları herkesin bildiği bir konudur. 16. yüzyıldan sonra da bu geleneğin etkilerinin devam ettiği muhakkaktır. Diğer yandan Yavuz Sultan Selim'in Çaldıran zaferinin ardından Horasan ve Tebriz'li sanatçıları İstanbul'a getirmesiyle bol figürlü Safevi üslûbunun ${ }^{57}$ İstanbul'a sirayet etmiş olmasi ${ }^{58}$, Şâh u Gedẩnın hem üretildiği ortam hem de üslûbunun anlaşılması bakımından önem taşır. Çünkü 1556 yılına kadar sernâkkaş olarak Osmanlı sarayında görev yapan saz üslûbunun yaratıcısı Şahkulu'da Tebriz'den gelen sanatçılar arasındadır. Şâh u Gedâ görülen hayvan tasvirli sayfa dekorasyonlarının Safevi dönemi yazmalarındaki hayvan tasvirli halkâr sanatıyla yakınlığı bu bağlamda düşünülebilir. Hayvan tasvirlerinin yer aldığı halkârlı sayfa düzenlemeleri Şiraz’da 16. yüzyılın

57 Safevi üslûbunun ortaya çıkmasında Timurlu-Herat ve Türkmen gelenekleri etkili olmuştur. Safevi dönemi kompozisyonlarında, diğer üslûplarda görülmeyen üslûplaştırılmış insan ve hayvan motifleri ve efsanevi yaratıklar sıkça işlenmiştir. Bk. Türkiye Diyanet Vakfı İslam Ansiklopedisi, Çiçek Derman, İstanbul: Türkiye Diyanet Vakfı Yayınları, 2012, “Tezhip Sanatında Üslûplar ve Sanatkârlar” maddesi; Türkiye Diyanet Vakfı İslam Ansiklopedisi, Ahmet Saim Arıtan, İstanbul: Türkiye Diyanet Vakfı Yayınları, 1993, “Ciltçilik” maddesi.

58 Türkiye Diyanet Vakfı İslam Ansiklopedisi, Çiçek Derman, İstanbul: Türkiye Diyanet Vakfı Yayınları, 2012, “Tezhip Sanatında Üslûplar ve Sanatkârlar” maddesi. 
ikinci yarısından itibaren üretilen yazmalarda yoğun olarak görülmektedir. ${ }^{59}$ Buna bir örnek 1574 tarihinde Şiraz'da yapılmış Şahname-i Firdevsî yazmasıdır. ${ }^{60}$ Yazmada resim ve metin kenarlarına yapılmış halkârlardaki nebat ve hayvan tasvirleri Şâh $u$ Gedẩnın kalıpla baskı tekniğinde yapılmış desenleri ile benzerdir (Resim 21).

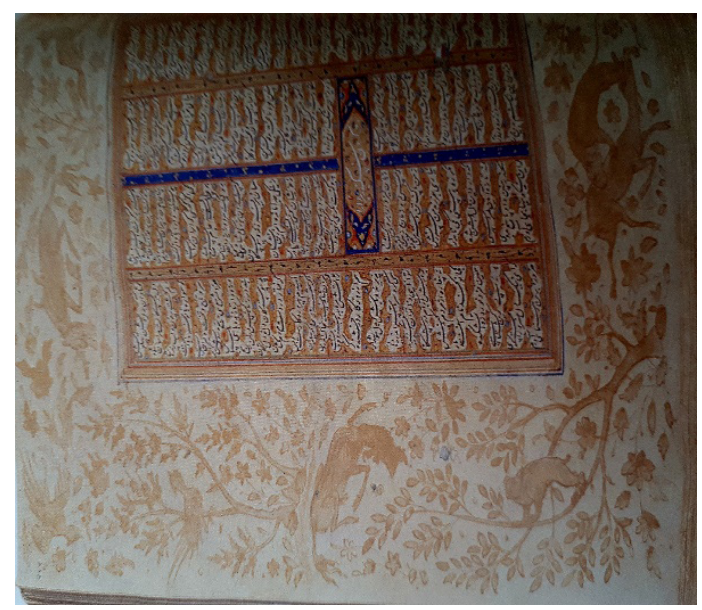

Resim 21. Şehname-i Firdevsî. 313 a.

\section{Değerlendirme ve Sonuç}

16. yüzyıl kitap sanatlarına genel çerçevede bakıldığında minyatür, hat, tezhip, halkâr, kat'ı gibi daha çok gelenekselleşmiş ve zahmetli yöntemler görülür. Şâh u Gedânın kalıpla boyama tekniği ise nispeten daha kolay bir uygulamadır. 1565 tarihli Muhibbi Divanı ya da Avrupa'ya dağılmış diğer benzer teknikle yapılmış örnekler düşünüldüğünde, yüzyılın teknikte yeni ve seri arayışları olarak görülebilir. Bu arayışın sebeplerinden biri de üretimi çabuk bir şekilde gerçekleştirme ve siparişi sahibine teslim etme isteği olmalıdır. Klasik tezhipli bir çalışmanın ne kadar zahmetli ve uzun soluklu bir iş olduğunu düşünürsek kalıpla boyanmış desenli sayfaların İstanbul'a kısa süreliğine gelen ve giderken beraberlerinde bir anı götürmek isteyen yabancılara sunulmuş bir tercih olduğu varsayılabilir. Çarşı esnafının da kolayına gelmiş olan bu teknik uzun ve zahmetli bir iş olan klasik tezhibe bir alternatif olmalıdır.

Çalışmaya konu olan Şâh u Gedâ nüshasının ne zaman, nerede, nasıl ve kimin için üretildiği ile ilgili sorular bilgi yetersizliği nedeniyle cevapsız kalmakla birlikte eldeki mevcut bilgilerden ya da dönemin olaylarından bazı çıkarımlar yapabilmek mümkündür. Öncelikle kalıpla boyama tekniğinin görüldüğü ve tarihi belli bir eser olan 1565-66 tarihli Muhibbi Divanı'nı (Topkapı Sarayı Müzesi Kütüphanesi, R. 738) baz aldığımızda Şâh u Gedầnın kalıpla boyama tekniğinin sonraki bir tarihte yapılmış olması fikri daha doğru gibi durmaktadır. Çünkü son üç gazelinin bizzat Kanunîn’in eliyle yazıldığı ve süslemelerinin Karamemi ye ithaf edildiği saray işi olan Muhibbi Divanı gibi önemli bir eserin bezemelerinin sonraki bir esere tesir etmiş olması akla daha yatkın gelmektedir. Böylece Şâh u Gedầnın süslemesinin, Muhibbi Diva-

59 Lâle Uluç, Türkmen Valiler Şirazlı Ustalar Osmanlı Okurlar, İstanbul: Türkiye İş Bankası Yayınları, 2006, s.226229.

60 Topkapı Sarayı Müzesi Kütüphanesi H. 1497, y. 312b-313a. 
ninı görmüş bir sanatçı tarafından yapılmış olduğu fikri de destek bulmuş olur. Bu kişi bizzat Karamemìnin kendisi olabileceği gibi atölyesindeki öğrencilerinden biri de olabilir. Hatta Muhibbi Divaninda uygulanan bu yeni tekniğin sarayın dışında duyulması Şâh u Gedầnın süslemelerinin çarşı esnafından biri tarafından yapıld1ğını bile düşündürebilir. Örneğin dönemin ünlü şairlerinden Zâtînnin, Taşlıcalinın yakın arkadaşı olması ve Beyazıt'ta bulunan kitapçı dükkânında tezhip işleriyle de uğraşması bu düşünceyi akla getirir. Çünkü Zatỉnin dükkânı dönemin sanatçı ve yazarlarının uğrak yerlerinden biri olup aynı zamanda dönemin yeni tekniklerinin de konuşulduğu bir yer olmalıdır. Ancak Zâtînin 1546'da ölmüş olması bu düşünceyi zayıf kilar.

Süslemelerin içeriğinde yer alan lale, sümbül, sıklamen, karanfil, zambak, aynı safa, nergis gibi motifler dönemin İstanbul'unun bahçe kültüründen esinlenilmiş olan natüralist çiçek üslubu ile yakından ilişkilidir. Ancak belli sayfalarda bu natüralist bahçenin aralarına serpiştirilmiş papağan, tavuskuşu, öküz ve tavşan gibi hayvan tasvirleri ise doğulu etkiler taşır ve dolayısıyla eser Osmanlı-Safevi kültürleri arasındaki etkileşimin ürünü gibi durmaktadır. Bu sebeple kitabın tarihine ve üslûbuna ilişkin soruya cevap olarak Şahkulu ve Karamemi arasında bir noktada olduğu söylenebilir. Yavuz Sultan Selim'le Çaldıran seferine katılan Taşlıcalı'nın bu sefer sırasında içlerinde Karamemìnin hocası Şahkulu olmak üzere sanatçılarla daha en başında tanışıp dostluk kurmuş olma ihtimali de bu sentezi desteklemektedir. Sonuç olarak eserin, Taşlıcalı'nın daha hayattayken istinsah edilmiş nüshalarından biri olduğu kabul edersek, kitabın süslenmesinde Taşlıcalinın sanatçı çevresi etkili olmuştur.

\section{Kaynakça}

And, Metin. Osmanlı Tasvir Sanatları: 1 Minyatür. İstanbul: Türkiye İş Bankası Kültür Yayınları, 2004.

Arıtan, Saim Ahmet. "Ciltçilik". Türkiye Diyanet Vakfı İslam Ansiklopedisi. 7. Cilt. İstanbul: 1993.

Artan, Tülay. “İfade Biçimleri ve Mecraları İstanbul ve Ötesi (1600-1800)”. Osmanlı Dünyası. Christine Woodhead. İstanbul: Alfa Yayıncılık, 1. Bs., 2018.

Atasoy, Nurhan. Hasbahçe Osmanlı Kültüründe Bahçe ve Çiçek. İstanbul: Aygaz A. Ş. Yayınlar1, 2002.

Çağman, Filiz. Kat' 1 Osmanlı Dünyasında Kâğıt Oyma Sanatı ve Sanatçıları. İstanbul: Aygaz A.Ş. Yayınları, 2004.

Demiriz, Yıldız. “16. Yüzyıl Kitap Sanatında Çiçek”. 16. Yüzyıl Osmanlı Kültür ve Sanatı Sempozyumu. İstanbul 11-12 Nisan 2000.

Derman, Çiçek. "Osmanlı Asırlarında Üslûp ve Sanatkarlarıyla Tezhip Sanatı". Osmanlı Ansiklopedisi 11. Ankara: Yeni Türkiye Yayınları, 1999.

Derman, Çiçek. “Tezhip Sanatında Üslûplar ve Sanatkârlar”. Türkiye Diyanet Vakfı İslam Ansiklopedisi 41. İstanbul: Türkiye Diyanet Vakfı Yayınlar, 2012.

Duran, Gülnur. “Karamemi”. Türkiye Diyanet Vakfı İslam Ansiklopedisi 24. İstanbul: Türkiye Diyanet Vakfı Yayınlar, 2012. 
Erünsal, E. İsmail. Osmanlılarda Sahaflık ve Sahaflar. İstanbul: Timaş Yayınları, 2013. Eyice, Semavi. "Elçi Hanı”. Türkiye Diyanet Vakfı İslam Ansiklopedisi 11. İstanbul: Türkiye Diyanet Vakfı Yayınları, 1995.

İnalcık, Halil. Has-bağçede Ayş u Tarab Nedîmler Şâîrler Mutrîbler. İstanbul: Türkiye İş Bankası Kültür Yayınları, 2015.

İsen, Mustafa. "XVI. Yüzyılda Siyasal, Kültürel ve Edeb̂̂ Hayat”. 16. Yüzyıl Türk Edebiyatı. Yekta Saraç, Muhsin Macit. Eskişehir: Anadolu Üniversitesi Açıköğretim Fakültesi Yayınları, 2011.

Kaya, Ali Bayram. “Taşlıcalı Yahyâ”. Türkiye Diyanet Vakfı İslam Ansiklopedisi 40. İstanbul: Türkiye Diyanet Vakfı Yayınları, 2011.

Kut, Günay. “Payitaht İstanbul'un Sultan Şairleri (Seyf ve'l-Kalem Sahipleri)”. İlmi Araştırmalar Dil, Edebiyat, Tarih İncelemeleri Dergisi. 9 (2000): 161-178.

Mesera, Gülbün. “Türk Tezhip ve Minyatür Sanatı. Sandoz Bülteni. 25 (1987): 9-21.

Mesera, Gülbün. “Kanuni Sultan Süleyman’ın Sernakkaşı Karamemi”. Hat ve Tezhip Sanatı. Ali Rıza Özcan. İstanbul: Kültür ve Turizm Bakanlı̆̆ı Yayınları, 2009.

Öz, Zeynep. "Bâkî Dîvânında Bahâriyye”. Divan Edebiyatı Araştırmaları Dergisi. 19 (2017): 217-254.

Pala, İskender. "Divan Edebiyatında İstanbul". Türkiye Diyanet Vakfı İslam Ansiklopedisi 23. İstanbul: Türkiye Diyanet Vakfı Yayınları, 2001.

Sönmez, Nedim, Miniatur Geschichten Die Sammlung Indischer Malerei Im Dresdner Kupferstıch-Kabinett. Dresden: Sandstein; Bilingual edition, 2017.

Şentürk, Atila Ahmet. "En Hazin Mersiye’nin Şairi: Taşlıcalı Yahya Bey”. Dil ve Edebiyat Dergisi. 26 (2011): 26-41.

Tavernier, Batiste Jean. Bir Fransız Seyyahın Gözüyle Topkapı Sarayı'nda Yaşam, Büyük Senyörün Sarayı. Çev., Hâluk Yanardağ. İstanbul: Parıltı Yayınları, 2005.

Teply, Karl. “Nemçe İmparatorlarının İstanbul'a Yolladığı Elçi Heyetleri ve Bunların Kültür Tarihi Bakımından Önemli Tarafları”. Çev., Bekir Sıtkı Baykal. Ankara Üniversitesi Dil ve Tarih-Coğrafya Fakültesi Tarih Bölümü Tarih Araştırmaları Dergisi. 12 (1969): 247-263.

Toprak, Adıgüzel Filiz. "1618 Tarihli Peter Mundy Albümü: Figürler Üzerine Bir Inceleme”. Sanat Dergisi. 22 (2012): 69-83.

Uluç, Lâle. Türkmen Valiler Şirazlı Ustalar Osmanlı Okurlar. İstanbul: Türkiye İş Bankası Yayınları, 2006.

Ünver, Süheyl Ahmet. “Türkiye'de Lale Tarihi”. Vakıflar Dergisi. 9 (1971): 265-276.

Ünver, Süheyl Ahmet. Müzehhip Karamemi. İstanbul: İstanbul Üniversitesi Yayınları, 1951.

Yoldaş, Kazım. “Taşlıcalı Yahyâ Bey Şâh u Gedâ (inceleme-metin)”. Yüksek Lisans Tezi, İnönü Üniversitesi,1993.

Internet Kaynakları

The British Museum. “PeterMundyalbümü”. Son Güncelleme 30 Mayıs 2018. http:// www.britishmuseum.org/research/collection_online/search.aspx?people $=2716$ $8 \&$ peo $A=27168-3-18$. 
Koninklijke Bibliotheek. "Sihouette paper”. Son Güncelleme 30 Mayıs 2018. https:// www.kb.nl/en/themes/book-art-and-illustrated-books/decorated-paper/ silhouette-paper.

Landesarchiv Baden-Württemberg. "Stammbuch Georg Ringler albümü". Son Güncelleme 29 Mayıs 2018. https://www.leobw.de/web/guest/detail// Detail/details/DOKUMENT/wlb_digitalisate/digibib-bsz4176277182/ Stammbuch+Georg+Ringler+-+Codhistoct5. 


\title{
A Different Practice in 16th Century Ottoman Book Arts: Flower Print Papers of Şâh u Gedâ Mathnawi
}

SAVAŞ MARAŞLI

\begin{abstract}
The study originates from the similarities found in the page ornamentations, made with a different method, of copy of Şâh $u$ Gedâ, one of the mathnawis of Taşlicalı Yahya, a poet of 16th century registered in Amasya Ind Bayezid Provincial Public Library inventory no 2067 and the ornamentations in some works of arts thought to have been created within the same century. Şâh u Gedâ's naturalist style flowers are reminiscent of the Karamemi style, the reference point for ornamentations of the era and are of a similar understanding and environment associated with the ornamentations included in Muhibbî Divanı (Topkapı Palace Museum Library: R.738 m.), dated 1565 and associated with Karamemi school. The fact that they are obtained through mould dressing method can be regarded as serial queries in technique. One of the reasons for this quest is the concerns in meeting the demands of foreigners crowding book markets emerging in certain localities of Istanbul of 16th century thus facilitating commercial activities in those markets. This can be seen in the albums thought to have been created with similar methods and having moved to Europe from Istanbul since 16th century. The inspiration for the flowers on the pages of Şâh u Gedâ, which is a love story taking place in Istanbul, originates from the flower gardens, a popular venue in Istanbul of the era, and the flowers raised there, the style is associated with flowers painted with mild colors and animal figures dispersed among them.
\end{abstract}

Keywords: Ottoman, 16th century, Şâh u Gedâ, Book arts, Naturalist style. 